\title{
TNF- $\alpha$ AND IL-6 AS BIOMARKERS OF IMPAIRED LUNG FUNCTIONS IN DIMETHYLACETAMIDE EXPOSURE
}

\section{TNF- $\alpha$ I IL-6 KAO BIOMARKERI OŠTEĆENOG FUNKCIONISANJA PLUĆA IZLAGANJEM DIMETILACETAMIDU}

\author{
Lütfiye Tutkun ${ }^{1}$, Servet Birgin Iritaş ${ }^{2}$, Serdar Deniz ${ }^{3}$, Özgür Öztan ${ }^{4}$, Sedat Abuşoğlu ${ }^{5}$, \\ Ali Ünlü ${ }^{5}$, Vugar Ali Türksoy ${ }^{6}$, Sultan Pınar Çetintepe ${ }^{7}$ \\ ${ }^{1}$ Department of Medical Biochemistry, Bozok University, Faculty of Medicine, Yozgat, Turkey \\ ${ }^{2}$ The Council of Forensic Medicine, Ankara, Turkey \\ ${ }^{3}$ Provincial Health Directorate, Malatya, Turkey \\ ${ }^{4}$ Department of Medical Management, HLC Medical Center, Ankara, Turkey \\ ${ }^{5}$ Department of Biochemistry, Selçuk University Faculty of Medicine, Konya, Turkey \\ ${ }^{6}$ Department of Public Health, Bozok University Faculty of Medicine, Yozgat, Turkey \\ ${ }^{7}$ Department of Occupational Medicine, Hacettepe University Faculty of Medicine, Ankara, Turkey
}

\section{Summary}

Background: Tumor necrosis factor- $\alpha$ (TNF- $\alpha$ ) and interleukin-6 (IL-6) are well-known biomarkers of systemic inflammation that have been associated with many diseases in the past. In this study, we aimed to determine the relationship between impaired lung functions and the levels of these biomarkers in DMAc exposed people.

Methods: 101 non-exposed control subjects (Group 1) and 109 DMAc-exposed workers from the polyvinyl chloride (PVC) industry were included in the study. In the next step, the exposed group was divided into two groups according to the level of exposure (Group 2 and 3). DMAc, TNF- $\alpha$, IL-6, creatinine, ALT, AST, GFR and standard spirometry measurements were carried out in all subjects.

Results: When compared to the control group, TNF- $\alpha$ and IL-6 levels were significantly high compatible with the increase of DMAc levels, in the exposed groups. Urinary DMAc Levels were $0.06 \mathrm{mg} / \mathrm{L}$ in the control group. This level is significantly low when compared to exposed and severely exposed group ( $2.43 \mathrm{mg} / \mathrm{L}$ and $3.17 \mathrm{mg} / \mathrm{L})$. TNF- $\alpha$ levels were $56.86 \mathrm{pg} / \mathrm{mL}, 145.52 \mathrm{pg} / \mathrm{mL}$ and 230.52 $\mathrm{pg} / \mathrm{mL}$ in control, exposed and severely exposed groups. IL-6 levels were found to be $38.08 \mathrm{pg} / \mathrm{mL}, 89.19 \mathrm{pg} / \mathrm{mL}$

\section{Kratak sadržaj}

Uvod: Faktor tumorske nekroze- $\alpha$ (TNF- $\alpha$ ) i interleukin- 6 (IL-6) su dobro poznati biomarkeri sistemske upale koja je povezana $s$ mnogim bolestima $u$ prošlosti. $U$ ovoj studiji nastojali smo utvrditi odnos između oštećenih funkcija pluća i nivoa tih biomarkera kod ljudi izloženih DMAc-u. Metode: U istraživanje je uključen 101 neizložen kontrolni subjekat (grupa 1) i 109 radnika izloženih DMAc iz industrije polivinil-hlorida (PVC). U sledećem koraku izložena grupa bila je podeljena u dve grupe prema nivou izloženosti (grupe 2 i 3). DMAc, TNF- $\alpha$, IL-6, kreatinin, ALT, AST, GFR i standardna spirometrijska merenja sprovedena su na svim ispitanicima.

Rezultati: U poređenju sa kontrolnom grupom, nivoi TNF- $\alpha$ i IL-6 bili su značajno visoki i u skladu s povećanjem nivoa DMAc kod izloženih grupa. Nivoi mokraćnog DMAc bili su 0,06 mg/L u kontrolnoj grupi. Ovaj nivo je značajno nizak u poređenju s izloženom i teško izloženom grupom $(2,43$ $\mathrm{mg} / \mathrm{L}$ i $3,17 \mathrm{mg} / \mathrm{L})$. Nivoi TNF- $\alpha$ bili su $56,86 \mathrm{pg} / \mathrm{mL}$, $145,52 \mathrm{pg} / \mathrm{mL}$ i $230,52 \mathrm{pg} / \mathrm{mL}$ u kontrolnoj, izloženoj i ozbiljno izloženoj grupi. Utvrđeno je da su nivoi IL-6 bili $38,08 \mathrm{pg} / \mathrm{mL}, 89,19 \mathrm{pg} / \mathrm{mL}$ i $116 \mathrm{pg} / \mathrm{mL}$ za kontrolnu, izloženu i ozbiljno izloženu grupu. Slično, nivo FEV1/FVC

Address for correspondence:

Servet Birgin Iritas (M.D., PhD)

Forensic Physician-Occupational Physician

Specialist of Forensic Toxicology and Chemistry

The Council of Forensic Medicine, Ankara, Turkey

e-mail: sbiritas@gmail.com 
and $116 \mathrm{pg} / \mathrm{mL}$ for control, exposed and severely exposed groups, respectively. Similarly, the FEV1/FVC ratio decreased especially in the severely exposed group ( $p$ 0.001).

Conclusions: In our study, results have revealed that TNFand IL-6 levels are promising biomarkers in the early diagnosis of lung function impairment in inhalational DMAc exposure.

Keywords: dimethylacetamide (DMAc), tumour necrosis factor- $\alpha$ (TNF- $\alpha)$, interleukin-6 (IL-6), pulmonary capacities, toxic inhalation

\section{Introduction}

The acute and chronic effects of industrial solvent exposure on the burden of occupational and environmental lung diseases are remarkable $(1,2)$. The harmful effects of these agents have been demonstrated in many diseases including cancer, chronic renal failure, peripheral or central neurotoxicity and developmental anomalies $(3,4)$.

Dimethylacetamide (DMAc) is an industrial solvent that is widely used in various applications in agrochemicals and pharmaceuticals, production of human-made fibres, industrial coatings and films (5). As it does not occur naturally, it is encountered as an anthropogenic compound. In the production of synthetic acrylic fibres, the polymerisation department where acrylic resins are prepared is the main source of DMAc exposure in the workplace. In this department, a hot water solution of DMAc is used to form acrylic fibres (wet spinning process), and it causes toxicity if protective measures are not sufficient (6). Its release to the environment, even after recovery treatment, its slow degradation and extensive use in the industry are significant public health problems (7).

Although the main route of exposure to DMAc is inhalation, dermal exposure is also possible (8). Urinary $\mathrm{N}$-methylacetamide (NMA) is accepted as the main parameter as a biological index, but there are several studies where the direct measurement of DMAc in urine has been used $(9,10)$. Previous studies showed that DMAc could cause liver damage (11, 12), hallucinations (13), and delirium (14) in chronically exposed people. In an experimental study, rats were exposed to 10 to $300 \mathrm{ppm}$ DMAc by inhalation for 3,6 or $12 \mathrm{~h} /$ day for a total of 10 exposures. Neither testicular damage, nor irritation to upper respiratory tract were detected (15). On the other hand, there are some conflicting studies about DMAc exposure. In a prenatal in vitro study about inflammatory mechanisms of endotoxins, DMAc was found to regulate the expression of proinflammatory cytokines interleukin-1 $\beta$, tumour necrosis factor- $\alpha$ (TNF- $\alpha$ ) and interleukin-6 (IL-6) (16).

TNF- $\alpha$ and IL- 6 are well-known biomarkers of systemic inflammation that has been associated with many diseases in the past. These proinflammatory cytokines have also been found to be increased in smanjen je, naročito kod izrazito izložene grupe (p 0,001). Zaključak: $U$ našem istraživanju rezultati su pokazali da su nivoi TNF i IL-6 obećavajući biomarkeri u ranoj dijagnozi pogoršanja funkcije pluća u ekspoziciji inhalacijskog DMAc.

Ključne reči: dimetilacetamid (DMAc), faktor tumorske nekroze- $\alpha$ (TNF- $\alpha)$, interleukin-6 (IL-6), plućni kapaciteti, toksično udisanje

studies about solvent exposure to the respiratory tract $(17,18)$.

Despite the widespread use of DMAc in the industry, this is the first study which evaluates the association of DMAc exposure level, proinflammatory cytokines and lung function parameters. In this study, we aimed to propose a method using the relationship between cytokine levels and lung function impairment for the early clinical diagnosis of respiratory involvement in DMAc exposure.

\section{Materials and Methods}

\section{Study Population}

This case-control study was performed on nonsmoker polyvinyl chloride workers examined at the Occupational and Environmental Medicine Department of the University Hospital of Bozok 2017. 210 subjects (101 control, 109 DMAc-exposed) were included in this study. The control group (Group 1) and the DMAc-exposed group consisted of local administrative staff and workers from the production unit, respectively. Inclusion criteria for the exposed group were to have high levels of urinary DMAc in their annual periodical examination, and the exclusion criteria, to have acute or chronic diseases including acute infections, chronic lung disease, diabetes mellitus, coronary vascular disease, rheumatological disease, cancer and smoking. Same exclusion criteria were applied to the control group. In the further analysis, the case group was divided into 2 groups according to the levels of exposure: exposed group (Group 2) (urinary $\mathrm{DMAc}=1-3 \mathrm{mg} / \mathrm{L}) \quad(\mathrm{N}=71$, urinary DMAc levels between 1.12-2.75 mg/L) and severely exposed group (Group 3) (urinary DMAc 3 $\mathrm{mg} / \mathrm{L})(\mathrm{N}=38$, urinary DMAc levels between 3-3.75 $\mathrm{mg} / \mathrm{L})$. Informed consent forms were taken from all participants. The ethical consent was approved by Keçiören Research and Educational Hospital Ethical Committee.

Collection of Biological Samples and Biochemical Analysis

Blood samples were taken from each participant to evaluate immunologic parameters. The sera of the 
blood samples were separated by centrifugation at $1500 \mathrm{rpm}$ for 10 minutes. Serum samples were transferred to $2 \mathrm{~mL}$ Eppendorf tubes and stored at $-20{ }^{\circ} \mathrm{C}$. Then, samples were transferred to the Occupational and Environmental Toxicology Laboratory of Yozgat Bozok University Science and Technology Application and Research Center (B LTEM) in a cold chain environment. Samples were stored at $-20{ }^{\circ} \mathrm{C}$ until analysis. IL- 6 and TNF- $\alpha$ levels were then studied by dissolving the samples. ELISA Kits (DIAsource, catalogue numbers: KAP1261 and KAP1751, respectively) were used for IL- 6 and TNF- $\alpha$ analyses. After the necessary pre-treatments had been made, samples were placed on microplates. Afterwards, microplates were carried to an ELISA (BMG LABTECH ClarioStar model) for reading. The wavelength was set at $450 \mathrm{~nm}$. 5-point calibration curves were used for IL-6, and TNF- $\alpha$ measurements. The $r^{2}$ values of the calibration curves were calculated as 0.9994 and 0.9992 , respectively. The control sample which was ready in the kit was used for verification. Linear regression was performed to obtain IL-6 and TNF- $\alpha$ results.

Urine samples were collected from each participant and placed in glass tubes with screw caps, and immediately placed on ice and stored at $-20{ }^{\circ} \mathrm{C}$. The DMAc levels of urine samples measured with Gas Chromatography-Mass Spectrometry (GC-MS) system (Shimadzu QP2010 ULTRA). $0.2 \mathrm{~mL}$ of urine was treated with $0.8 \mathrm{~mL}$ of 2-propanol. This mixture was shaken and then dried with $0.2 \mathrm{~g}$ of sodium sulfate $\mathrm{Na}_{2} \mathrm{SO}_{4}$ (Sigma Aldrich). Then, the final mixture was centrifuged for 10 minutes at $3000 \mathrm{rpm}$. A $0.2 \mathrm{~mL}$ of an aliquot of supernatant was again mixed with 0.8 $\mathrm{mL}$ of 2-propanol, then $1 \mu \mathrm{L}$ was drawn for GC-MS analysis.

An autosampler injection system coupled with a Shimadzu-QP2010 ultra (Kyoto, Japan) gas chromatography plus a mass spectrometric detector was used for DMAc analysis as described by Perbellini et al. (9). The injection volume was $1 \mu \mathrm{L}$. The calibration curve was constructed using six different concentrations $(0.05 \mathrm{mg} / \mathrm{L}, 0.1 \mathrm{mg} / \mathrm{L}, 0.5 \mathrm{mg} / \mathrm{L}, 1$ $\mathrm{mg} / \mathrm{L}, 2.5 \mathrm{mg} / \mathrm{L}$ and $5 \mathrm{mg} / \mathrm{L}$ ) of dimethylacetamide (Sigma Aldrich).

\section{Spirometry Measurements}

Pulmonary function tests were applied to all participants. Standard spirometry measurement was carried out by a dry-seal-spirometry (Zan 100, Spire Health Inc., Oberthulba, Germany). Lung function tests were defined in accordance with the American Thoracic Society standards (19). Lung function test data included forced vital capacity (FVC), forced expiratory volume in 1 second (FEV1), FEV1/FVC actual, and peak expiratory flow (PEF).

\section{Statistical Analysis}

The Statistical Package for Social Sciences (SPSS 24, Inc., Chicago, IL, USA) was used for statistical analysis. The t-test was carried out to determine participants' characteristics among the control and case groups (Table I). Pearson test was used to evaluate the correlations between lung function parameters and toxicological-biochemical variables among the two groups (Table II). One way ANOVA was used to compare the averages of more than 2 independent variables among the three groups. All tests were considered significant at $p<$ 0.05 .

\section{Results}

The total number of participants were 210 males including control group with 101 subjects and DMAc-exposed group with 109 subjects. There was no statistically significant difference between groups for ages (34.4 \pm 6.4 years for control and 35.8 26.7 years for main study groups, $p=0.121$ ). Urinary DMAc levels, TNF- $\alpha$ and IL- 6 were significantly higher in the DMAc-exposed group than the control group $(p<0.001)$ while the values of FEV1 and FVC were significantly lower in the DMA-exposed group than control group $(p<0.001)$ (Table I). No difference between groups was observed for FEV/FVC, PEF, creatinine, ALT, and AST (Table I).

In Pearson correlation analysis, strong positive correlations between urinary DMAc levels and serum TNF- $\alpha(r=0.895, p<0.001)$, serum IL-6 $(r=0.869$, $p<0.001)$ and a negative correlation with FVC $(r=-$ $0.873, p<0.001)$, FEV1 $(r=-0.867, p<0.001)$ and FEV1/FVC ( $r=-150, p<0.001)$ were found (Table II). There was no correlation between urinary DMAc levels and serum ALT, AST, GGT, GFR, creatinine and age ( $p>0.05$ for all)

In further analysis, the DMA-exposed group was divided into 2 groups, the exposed one (Group 2) $(n=71)$ and the severely exposed one (Group 3) $(n=38)$ as mentioned in the method section. The levels of DMA, TNF- $\alpha$ and IL- 6 were significantly different and had an increasing pattern from control (Group 1) to the severely exposed group $(p<0.001)$ (Table III). FEV1 and FVC values in litres had a decreasing pattern from Group 1 to Group 3, and there was a significant difference between groups. (FEV1: 4.52, 3.68, 3.03; FVC: 5.04, 4.10, 3.53, respectively) $(p<0.001)$. The ratio of FEV1/FVC was the lowest in the severely exposed group when compared to the others $(0.89,0.89,0.86$, respectively) $(p<0.001)$ (Table II). The difference between $P E F$, hepatic enzymes and renal markers was not significant between groups ( $p>0.05)$. 
Table I Main Laboratory Parameters of Group 1 (Control) and Group 2 + Group 3 (DMAc-exposed).

\begin{tabular}{|c|c|c|c|}
\hline & $\begin{array}{c}\text { Control }(n=101) \\
(\text { Group 1) }\end{array}$ & $\begin{array}{l}\text { DMAc-exposed ( } n=109) \\
\text { (Group } 2+\text { Group 3) }\end{array}$ & $p$ \\
\hline Dimethylacetamide $(\mathrm{mg} / \mathrm{L}) * *$ & $0.05 \pm 0.04$ & $2.68 \pm 0.42$ & $<0.001^{*}$ \\
\hline TNF- $\alpha(p g / m L)$ & $56 \pm 30$ & $175 \pm 49$ & $<0.001 *$ \\
\hline IL-6 (pg/mL) & $38 \pm 21$ & $98 \pm 19$ & $<0.001^{*}$ \\
\hline FEV1 (L) & $4.52 \pm 0.39$ & $3.45 \pm 0.39$ & $<0.001^{*}$ \\
\hline FVC (L) & $5.04 \pm 0.42$ & $3.90 \pm 0.38$ & $<0.001^{*}$ \\
\hline $\mathrm{FEV} / \mathrm{FVC}$ & $0.89 \pm 0.06$ & $0.88 \pm 0.05$ & 0.079 \\
\hline $\operatorname{PEF}(\mathrm{L} / \mathrm{min})$ & $8.33 \pm 1.56$ & $8.23 \pm 1.56$ & 0.651 \\
\hline Creatinine $(\mu \mathrm{mol} / \mathrm{L})$ & $64.53 \pm 14.14$ & $66.30 \pm 15.02$ & 0.449 \\
\hline $\operatorname{ALT}(U / L)$ & $23 \pm 12$ & $26 \pm 16$ & 0.129 \\
\hline AST (U/L) & $24 \pm 8$ & $25 \pm 9$ & 0.201 \\
\hline GFR (mL/min) & $138 \pm 50$ & $132 \pm 46$ & 0.401 \\
\hline
\end{tabular}

TNF- $\alpha$ : Tumour necrosis factor; IL-6: Interleukine 6; FEV: forced expiratory volume; FVC: forced vital capacity; PEF: peak expiratory flow; AST: Aspartate transaminase; ALT: Alanine transaminase; GFR: Glomerular filtration rate. Values were presented as mean \pm standard deviation. ${ }^{*} \mathrm{p}<0.001$ : significant, ** urinary level

Table II Pearson Correlation ( $r$ ) Coefficients of Group 1 and Group 2-3.

\begin{tabular}{|c|c|c|c|c|c|c|c|}
\hline & DMA & TNF & IL6 & FEV1 & FVC & $\begin{array}{l}\text { FEV1 } \\
\text { /FVC }\end{array}$ & PEF \\
\hline DMA & 1 & & & & & & \\
\hline TNF & $0.895^{* *}$ & 1 & & & & & \\
\hline IL6 & $0.869 * *$ & $0.940 * *$ & 1 & & & & \\
\hline FEV1 & $-0.867 * *$ & $-0.901 * *$ & $-0.876 * *$ & 1 & & & \\
\hline FVC & $-0.873^{* *}$ & $-0.860 * *$ & $-0.835^{* *}$ & $0.913 * *$ & 1 & & \\
\hline $\begin{array}{l}\text { FEV1 } \\
\text { /FVC }\end{array}$ & $-0.150 *$ & $-0.262^{* *}$ & $-0.245^{* *}$ & $0.377 * *$ & -0.027 & 1 & \\
\hline PEF & -0.028 & 0.000 & -0.008 & 0.039 & -0.007 & 0.116 & 1 \\
\hline
\end{tabular}


Table III Distribution of DMA, TNF- $\alpha$, IL-6, pulmonary function tests, ages and routine biochemical tests among the 3 groups.

\begin{tabular}{|c|c|c|c|c|}
\hline & Group & Mean & Std. Deviation & $P$ \\
\hline \multirow{3}{*}{$\begin{array}{l}\text { Dimethylacetamide } \\
(\mathrm{mg} / \mathrm{L})^{* *}\end{array}$} & 1 & .06 & .05 & \multirow{3}{*}{$<0.001 *$} \\
\hline & 2 & 2.43 & .25 & \\
\hline & 3 & 3.17 & .22 & \\
\hline \multirow{3}{*}{ TNF- $\alpha(p g / m L)$} & 1 & 56.86 & 30.06 & \multirow{3}{*}{$<0.001 *$} \\
\hline & 2 & 145.52 & 23.17 & \\
\hline & 3 & 230.52 & 36.61 & \\
\hline \multirow{3}{*}{ IL-6 (pg/mL) } & 1 & 38.08 & 21.05 & \multirow{3}{*}{$<0.001^{*}$} \\
\hline & 2 & 89.19 & 10.28 & \\
\hline & 3 & 116.16 & 21.70 & \\
\hline \multirow{3}{*}{ FEV1 (L) } & 1 & 4.52 & .39 & \multirow{3}{*}{$<0.001 *$} \\
\hline & 2 & 3.68 & .19 & \\
\hline & 3 & 3.03 & .33 & \\
\hline \multirow{3}{*}{ FVC (L) } & 1 & 5.04 & .43 & \multirow{3}{*}{$<0.001^{*}$} \\
\hline & 2 & 4.10 & .22 & \\
\hline & 3 & 3.53 & .35 & \\
\hline \multirow{3}{*}{ FEV1/FVC (L) } & 1 & .89 & .06 & \multirow{3}{*}{$<0.001 *$} \\
\hline & 2 & .89 & .05 & \\
\hline & 3 & .86 & .04 & \\
\hline \multirow{3}{*}{ PEF (L/min) } & 1 & 8.33 & 1.56 & \multirow{3}{*}{0.6} \\
\hline & 2 & 8.15 & 1.61 & \\
\hline & 3 & 8.39 & 1.46 & \\
\hline \multirow{3}{*}{$\begin{array}{l}\text { Creatinine } \\
(\mu \mathrm{mol} / \mathrm{L})\end{array}$} & 1 & 64.53 & 14.14 & \multirow{3}{*}{0.6} \\
\hline & 2 & 67.18 & 15.91 & \\
\hline & 3 & 65.41 & 15.90 & \\
\hline \multirow{3}{*}{$\operatorname{ALT}(\mathrm{U} / \mathrm{L})$} & 1 & 23.45 & 12.60 & \multirow{3}{*}{0.28} \\
\hline & 2 & 27.01 & 16.46 & \\
\hline & 3 & 25.57 & 15.63 & \\
\hline \multirow{3}{*}{ AST (U/L) } & 1 & 24.09 & 8.02 & \multirow{3}{*}{0.17} \\
\hline & 2 & 26.45 & 8.98 & \\
\hline & 3 & 24.08 & 9.60 & \\
\hline \multirow{3}{*}{ AGE } & 1 & 34.40 & 6.48 & \multirow{3}{*}{0.085} \\
\hline & 2 & 36.50 & 6.40 & \\
\hline & 3 & 34.30 & 6.70 & \\
\hline
\end{tabular}

TNF- $\alpha$ : Tumour necrosis factor; IL-6: Interleukine 6; FEV: forced expiratory volume; FVC: forced vital capacity; PEF: peak expiratory flow; AST: Aspartate transaminase; ALT: Alanine transaminase; GFR: Glomerular filtration rate. Values were presented as mean \pm standard deviation. ${ }^{*} \mathrm{p}<0.001$ : significant, ${ }^{* *}$ urinary level 


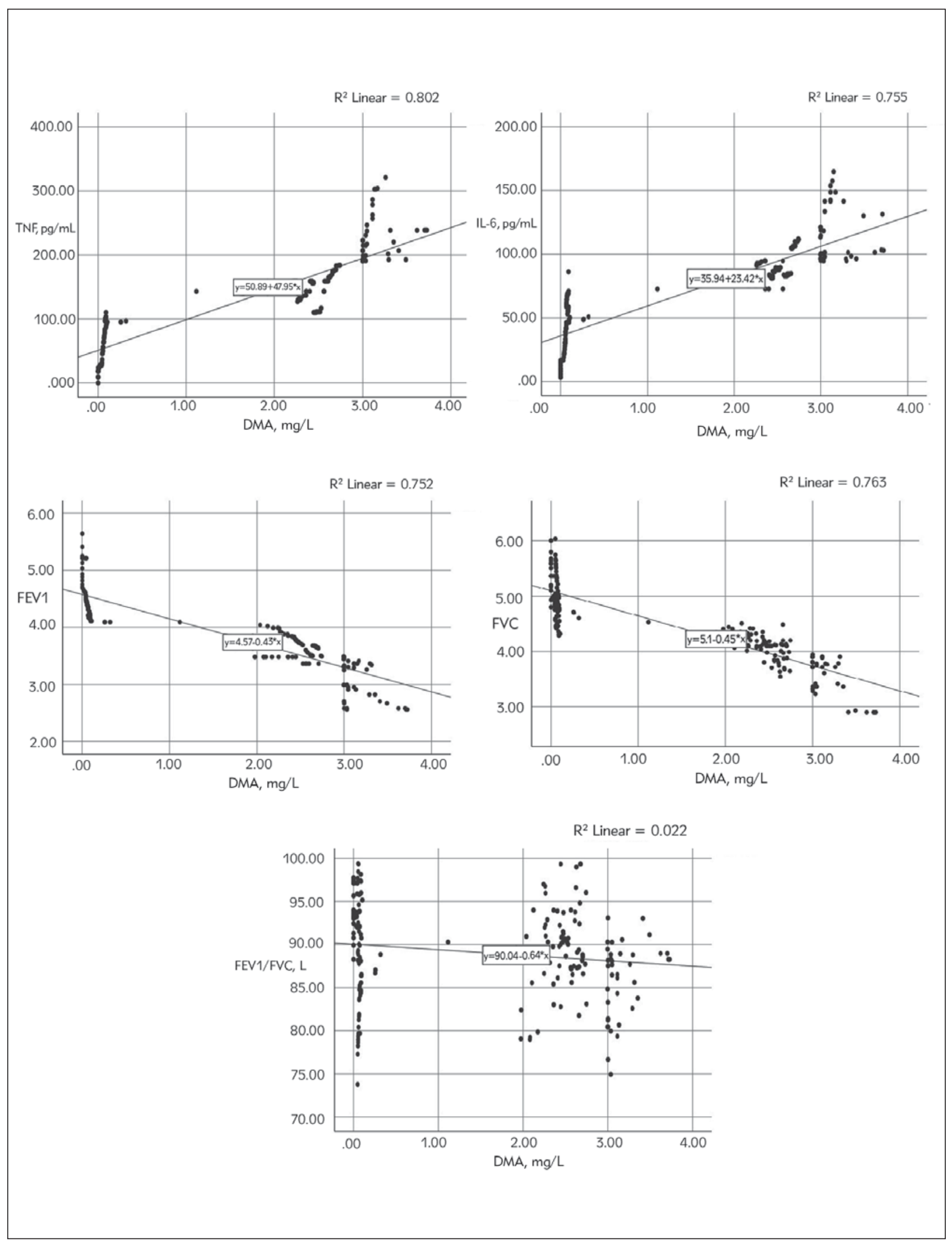

Figure $1 \mathrm{R}^{2}$ values and scatter graphics DMAc and TNF- $\alpha$, FVC, IL-6, FEV1, FEV1/FVC. 


\section{Discussion}

To our knowledge, this is the first study that evaluates the association between proinflammatory cytokines and impaired lung functions in DMAcexposed people. The similarity between ages and characteristics of the groups gave us the opportunity to have similar cutoff levels for biochemical values. In DMAc-exposed group DMAc, TNF- $\alpha$ and IL- 6 were detected significantly higher than the control group $(p<0.001)$. Additionally, DMAc had a positive correlation with serum TNF- $\alpha(r=0.895, p<0.001)$, and serum IL-6 ( $r=0.869, p<0.001)$ levels. Although there are studies that support the correlation between DMAc exposure and inflammation, it is possible to see some conflicting results in a few publications. Sundaram et al. (16) studied the proinflammatory response in endotoxin-induced preterm birth in mice and suggested that DMAc mediated the regulation of the expression of cytokines (IL- $\beta$, TNF- $\alpha$ and IL-6), supporting the evidence of the anti-inflammatory role of DMAc. In another study, Chinese researchers conducted a cross-sectional study among trichloroethylene-exposed workers where no significant differences in levels of IL- 6 or TNF- $\alpha$ were observed (20). However, the increased levels of TNF- $\alpha$ and IL6 in our study seem to demonstrate the proinflammatory response to DMAc exposure.

In our study, FEV1 and FVC values were found significantly lower in the DMA-exposed group than the control group $(p<0.001)$. The difference between the groups was not observed for FEV/FVC, PEF, creatinine, ALT and AST values. DMAc levels were negatively correlated with FVC ( $r=-0.873$, $p<0.001)$. Similar findings have been presented in an environmental study that investigates the relationship between petrochemical pollution and lung function testing parameter (21). In another casecontrol study on respiratory findings of workers who were exposed to industrial solvents in a gun factory, the same changes on the lung capacities were observed (22). The FEV1/FVC levels were found to be lowest in the severely exposed group when

\section{References}

1. Schenker MB, Jacobs JA. Respiratory effects of organic solvent exposure. Tubercle Lung Dis 1996; 44: 4-18.

2. Uzma N, Salar BM, Kumar S, Aziz N, David MA, Reddy VD. Impact of organic solvents and environmental pollutants on the physiological function in petrol filling workers. Int J Environ Res Public Health 2008; 5(3): 139-46.

3. Züngün C, Yılmaz FM, Tutkun E, Yılmaz H, Uysal S. Assessment of serum $100 B$ and neuron specific enolase to evaluate the neurotoxic effects of organic solvent exposure. Clin Toxicol (Phila) 2013; 51: 748-51. compared to the others $(p<0.001)$ in our study. This indicates the decrement in pulmonary capacities as the exposure intensity increases. Irritation to lungs may be expected by DMAc exposure via inhalation, but the literature was limited to a few studies. $40 \mathrm{ppm}$ of DMAc exposure caused minimal signs of irritation on the lungs of rats histopathologically, while 100 ppm and above levels caused clinically significant dose-related upper respiratory tract toxicity (23). Although previous occupational studies in acute and chronic exposure to DMAc confirmed liver toxicity relying on $\mathrm{ALT}$ and $\mathrm{AST}$ level alterations $(8,11,12)$, our results are not consistent with these findings.

Limitations of this study were lack of DMA air measurements of the workplace environment and selection bias due to the design of the study. Strengths of this study were being the first study evaluating DMA exposure and pulmonary function test associations, and the elimination of confounding factors such as smoking and having chronic diseases.

\section{Conclusion}

Organic solvent exposure is an important health hazard that can occur occupationally and environmentally. DMAc exposure may trigger proinflammatory responses and cause a decrement in lung functions among polyvinyl chloride workers. In the future, in order to identify the underlying patterns of DMA exposure levels in workers, biomonitoring could be improved, and pulmonary function tests could be carried out on these workers with pro-inflammatory marker levels. Future studies in a cohort setting should be designed to enlighten the causation between DMA exposure and pulmonary function disturbances.

\section{Conflict of interest statement}

The authors stated that they have no conflicts of interest regarding the publication of this article.

4. Kaukiainen A, Akila R, Martikainen R, Sainio M. Symptom screening in detection of occupational solvent-related encephalopathy. Int Arch Occup Environ Health 2009; 82: 343-55.

5. ECHA (European Chemicals Agency). Draft background document for N,N-Dimethylacetamide. Document developed in the context of ECHA's fourth recommendation for the inclusion of substances in Annex XIV. 20 June 2012.

6. Kohler T, Peterek S, Gries T. Wet spinning PAN-fibers from aqueous solutions of $\mathrm{ZnCl}_{2}$ and $\mathrm{NaSCN}$. IOP Conf SerMat Sci 2017; 254 
7. Chen X, Yang C, Wang W, Ge B, Zhang J, Liu Y, Nan Y. Biodegradation of N,N-dimethylacetamide by Rhodococcus sp. strain B 83 isolated from the rhizosphere of pagoda tree. J Environ Sci (China) 2017; 53: 88-98.

8. Kennedy GL. Toxicology of dimethyl and monomethyl derivatives of acetamide and formamide: a second update. Crit Rev Toxicol 2012; 42: 793-826.

9. Perbellini L, Princivalle A, Caivano M, Montagnani R. Biological monitoring of occupational exposure to N,Ndimethylacetamide with identification of a new metabolite. Occup Environ Med 2003; 60: 746-51.

10. Cendana M, Lee S, Upadhyay PJ et al. An HPLC-UV method for determining plasma dimethylacetamide concentrations in patients receiving intravenous busulfan. Biomed Chromatogr 2017; 31 (7).

11. Jung SJ, Lee CY, Kim SA et al. Dimethyacetamideinduced hepatic injuries among spandex fibre workers. Clin Toxicol 2007; 45: 435-9.

12. Lee CY, Jung SJ, Kim SA, Park KS, Ha BG. Incidence of dimethylacetamide induced hepatic injury among new employees in a cohort of elastane fibre workers. Occup Environ Med 2006; 63: 688-93.

13. Su TC, Lin PH, Chiu MJ et al. Dimethylacetamide, ethylenediamine and diphenylmethane diisocyanate poisoning manifest as acute psychosis and pulmonary edema: Treatment with hemoperfusion. J Toxicol-Clin Toxic 2000; 38: 429-33.

14. Marino G, Anastopoulos H, Woolf AD. Toxicity associated with severe inhalational and dermal exposure to dimethylacetamide and 1,2-ethanediamine. J Occup Environ Med 1994; 36: 637-41.

15. Kinney LA, Burgess BA, Stula EF, Kennedy GL. Inhalation studies in rats exposed to dimethylacetamide from 3 to
12 hours per day. Drug Chem Toxicol 1993; 16: 17594.

16. Sundaram S, Ashby CR, Jr., Pekson R et al. N,N-dimethylacetamide regulates the proinflammatory response associated with endotoxin and prevents preterm birth. Am J Pathol 2013; 183: 422-30.

17. Mutray A, Jung D, Klimek L, Kreiner C. Effects of an external exposure to 200 ppm methyl ethyl ketone on nasal mucosa on healthy volunteers. Int Arch Occup Environ Health 2002; 197-200.

18. Karagözler AA, Mehmet N, Batçio lu K. Effects of longterm solvent exposure on blood cytokine levels and antioxidant enzyme activities in house painters. J Toxicol Environ Health A 2002; 65(17): 1237-46.

19. Laszlo, G. Standardisation of lung function testing: help guidance from ATS/ERS Task Force. Thorax 2006; 61(9): 744-6.

20. Avci E, Avci AG. Important biomarkers that play a role in the chronic obstructive pulmonary disease process. J Med Biochem 2018; 37: 45-53.

21. Wichmann FA, Müller A, Busi LE, Cianni N, Massolo L, Schlink U, Porta A, Sly PD. Increased asthma and respiratory symptoms in children exposed to petrochemical pollution. J Allergy Clin Immunol 2009; 123(3): 632-8.

22. Çakmak A, Ekici A, Ekici M, Arslan M, teginli A, Kurtipek $\mathrm{E}$, Kara T. Respiratory findings in gun factory exposed to solvents. Resp Med 2004; 98(1): 52-6.

23. OECD O.f.E.C-o.a.D. N,N-Dimethylacetamide (DMAc) CAS No: 127-19-5. SIDS initial assessment report for 13th SIAM. Bern, Switzerland, 2011; 3-23. 